\title{
THE FAREWELL DISCOURSE OF THE EVANGELIST JOHN AND ITS JEWISH HERITAGE
}

\author{
Ernst Bammel
}

\section{Summary}

Consideration of the Gattung of the Jewish Farewell Speeches shows that the Johannine discourse (apart from 13:1ff.) belongs to this genre, which exercised its influence on other parts of the Gospel as well. Materially it is different; the standing features of the Jewish speeches are reworked completely. This is indicated by eight points of comparison. The Farewell Discourses happened to be replaced very soon by the Christian genre of the Speeches of the resurrected Lord. Still, they stand out as a remarkable theological achievement accomplished within a very short span of time.

I.

The farewell discourse is the most extended entity on its own in the gospels-containing more verses than even the Sermon on the Mount. It is also more unified than the Sermon on the Mount. It requires special consideration. It lends itself to comparison with formations in Jewish literature. The fact that Käsemann described it as 'The Testament of Jesus'1 may give additional point to such a comparison, although it must be said that Käsemann himself, in spite of the title of his book, did not show an interest in this aspect.

The Testament is a common literary genre in Jewish literature. More than 20 pieces of this description have come down to us: some, perhaps many, have perished. 2 They are marked by significant features. Special tribute is to be given to Stauffer, the man of genius, who was the first scholar to notice and to describe the Gattung and to characterise it. ${ }^{3}$ Additional

\footnotetext{
1E. Käsemann, Jesu letzter Wille nach Johannes 17 (Tübingen, J.C.B. Mohr 1971).

2Three more testaments, deriving from Qumran, were published in R.H. Eisenman \& M. Wise (eds.), The Dead Sea Scrolls Uncovered: the first complete translation and interpretation of 50 key documents withheld for over 35 years (Shaftesbury, Element 1992) 145-160.

3E. Stauffer, 'Abschiedsreden' in Reallexikon für Antike und Christentum 1 (1950) 29-35; Die Theologie des Neuen Testaments (Stuttgart 1940; ET 1955)
} 
contributions were made by J. Becker, ${ }^{4}$ E. v. Nordheim, ${ }^{5}$ E. Cortes $^{6}$ and R.W. Paschal. ${ }^{7}$

The Testament was in fact the most popular literary genre in the time of Jesus-so much so that writings which had a different scope came to be incorporated into this Gattung. The 'Testament of Job', for example, is nothing but a rehash of the biblical story, but it has been prefixed by the announcement of Job to his sons that, because his death is approaching, he wants to inform them about the events of his life and, accordingly, it has had appended to it the description of his death, the lifting up of his soul and the laying to rest of his body.

Equally this popular form invaded documents which are basically and to a large extent different: Pseudo-Philo is a summary of the Pentateuch, but chapter 33 is a testament, I Enoch is the description of a part of Genesis but chapters 55-67 were a testament. 4 Ezra acquires characteristics of a testament. The last chapter of the book starts with the comment: put your house in order, admonish the people; it goes on with the description of the writing down of the law, the part which is to be promulgated and the much greater part which is to be kept secret and concludes with Esdras' withdrawal to heaven.

Nor is the Gattung confined to the Fourth gospel in the New Testament. Luke 9:31 is the angelic announcement of the death of the chosen one, as is typical for the testaments. Luke 22:28ff. is the commission the dying leader gives to his disciples. Taken together the two passages constitute the beginning and the end of a testament, whereas the central piece, the farewell discourse properly speaking, is less obviously brought out in the third gospel. (There are perhaps elements in ch. 12). Paul's speech at Miletus is a farewell speech, 'das Testament des Paulus' the title of a recent

327-30; his proposal was taken up, little altered, by R.E. Brown, The Gospel According to John (New York 1970) 597f.

4J. Becker, Die Testamente der zwölf Patriarchen (Gütersloh 1974).

5E. v. Nordheim, Die Lehre der Alten I/II (Leiden 1980-85).

6E. Cortes, Los discursos de adiós de Gn 49 a Jn. 13-17 (Barcelona 1976).

${ }^{7}$ R.W. Paschal, The Farewell Prayer of Jesus: A Study of the Gattung and the Religious Background of John 17 (Diss, Cambridge 1982). 
monograph on it. ${ }^{8}$ Even 2 Peter has been characterised as a testament.9

\section{II.}

There is no doubt that the chapters of John in question are a farewell discourse. The verse that is normally taken to be the beginning of it, 13:31, is followed by the announcement of the parting of ways (13:33). The motif occurs in different shades time and again in John (e.g. 16:16). It is dominant at the end, in what is a testament properly speaking. Jesus bequeaths what had been given to him to his disciples, to those who are his own (17:24ff.). It is a disposition with a juridical slant.10

Does this, however, give the full picture? Certainly the motif of departure or imminent glorification is in the forefront of these chapters. Is it, however, absent from the previous passages? The three motifs which are so prominent in the following chapters are contained in 12:28, 31f.: Jesus' exaltation, the кpiois of this world and the involvement of the disciples. The passage in John 12 is indeed a farewell discourse of its own, an entity for which a scenario is given. ${ }^{11}$ It is a discourse the progression of which is facilitated by interruptions or questions ${ }^{12}$ and which has its climax in a commission given to the disciples. 13 This is obscured by material of a different kind (33f., 41-3) and the addition of a revelation speech introduced

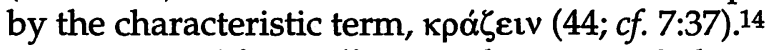

Jesus' farewell saying has appended to it here a remark of the evangelist on blinding of the eyes and hardening of the heart. The same motif occurs, although in a varied form, in 9:39. And indeed, a farewell motif is also present at the beginning of

${ }^{8}$ O. Knoch, Die 'Testamente' des Petrus und Paulus (Stuttgart 1973). H.-J. Michell, Die Abschiedsrede des Paulus an die Kirche Apg 20:17-38 (München 1973).

${ }^{9}$ E. Kühl, Die Briefe Petri und Judae (Göttingen 1897).

10E. Bammel, Jesu Nachfolger (Heidelberg 1988) 78ff.

${ }^{11}$ The Greeks come to Jesus rather than him going to them (7:35). Moreover the speech is directed to everyone, in contrast to what follows. It contains Jesus' closing statement to Jewish messianism (12:34ff). There is even a closing prayer v. 27f., cf. 17:1ff. Is an ascension hinted at in v. 36 ? $1229-34$, as is the case in 13:46-14:22 on the side of the disciples.

$1335 ;$; $f$. 17-26.

${ }^{14} C f .1: 15 ; 7: 28,37 ;$ Rom. 8:15; 9:27; Gal. 4:6. 


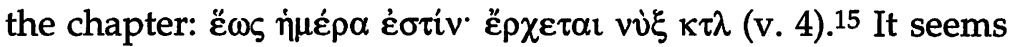
that farewell motifs invaded and overlaid material of a different kind. We encounter a tendency to turn one page after the other into a farewell discourse. Disjecta membra invaded even earlier passages: 7:34; 8:21.

It becomes apparent that although the farewell discourse is a Teilform in the present gospel it exercised a radiating influence. If I may exaggerate slightly, the whole gospel is in fact on the verge of becoming, or being turned into a farewell discourse.

\section{III.}

What part does the foot-washing play? Is it an integral part of the farewell discourse? At first sight, it looks like an ideal setting for the speech. There are, however, differences as well. The saying about the servant who is not above his master which is made use of in 13:16 and 15:20 has a different function in each of these cases. More important: the question of qualification is at stake. This is fitting for the beginning rather than the end of a connection or $\mu \varepsilon \rho{ }^{\prime} \rho(13: 8)$. The scene described so vividly conveys much more the association of an initiatory rite than that of a farewell action.

Nor does the meal play a significant role in Jewish farewell discourses. It is mentioned in passing twice ${ }^{16}$ that the person departing had a meal but this is done only in order to bring out that he was full of vigour and capax mentis to the last of his days. ${ }^{17}$ Nor is there a substantial connection between footwashing and farewell discourse. We must deduce, therefore, that the linkage was superimposed. The bridge is, of

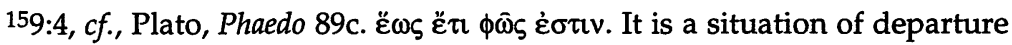
in which Socrates utters these words. It is, however, only a casual remark in this context..

16Testament of Naphtali 1:2ff; 9:2.

17There may be a juridical ingredient. A testament which was issued while the person concerned was in good health, is eo ipso valid; it cannot be altered or retracted (while it is different from a will promulgated from the sickbed). This is the situation in Jewish law. It has a special dignity and commands respect. The following speech, whether it is pregnant with juridical notions or not, is affected by this. Its value is thereby increased. 
course, to be found in Jesus' speech, which may be interpreted, although not necessarily so, 18 in terms of a testament.

Speeches are very common on the occasion of a meal or rather the meal is one of the most common settings for a speech. Tischgespräch is a Gattung of its own-this time in Greek literature. In detail, it contains the following elements: ${ }^{19}$ a jealous argument, the withdrawal of an unwelcome guest, the delay of the decisive speech until he has left and, although not very frequently, the peripatos after the meal (Martin, 147f.) and the appearance of intruders at this stage. These elements are certainly present in John 13 (Jn 18 at the beginning) 20 -apart from the philoneikia which is in the forefront in Luke 22:24, but which may just become apparent in John 13:22ff. as well. ${ }^{21}$

It may be that the prominence of these details in Greek literature stimulated the composer of chapter 13 to bring out the corresponding features 22 in what had been a footwashing scene originally, to emphasise the meal character and to link it with the series of farewell discourses.

\section{IV.}

It is high time to cast a closer look at the Jewish writings in order to be able to carry out a comparison. It is mainly in two directions that the last speech of a departing man of God unfolds. He looks back to his own life and beyond, to its achievements and shortcomings. This may go so far that a sketch on God's dealings with Israel, and their response (or failure to live up to God's demands) is included. In consequence of this, detailed admonitions and reflections follow. The emphasis varies: Pseudo-Philo 23 focuses on God's doings with Israel in the past, whereas the Testaments of the 12 Patriarchs concentrate on their individual history and draw the

${ }^{18}$ Alternatively it may be the induction into the second grade of fellowship.

${ }^{19}$ See J. Martin, Symposion: Die Geschichte einer literarischen Form (Paderborn 1931) 33ff.

2018:1 may be compared with the $\pi \varepsilon p i \pi \alpha \tau{ }^{\prime}, 18: 2 \mathrm{ff}$ with the bursting in of an unwelcome band.

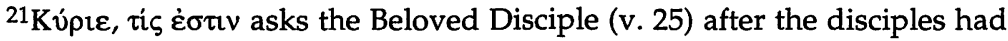
searched their souls (v. 22).

229:15, vं ó $\delta \varepsilon \imath \gamma \mu \alpha$ could have served as a starting point for the change; $v$.

1f. shows marks of redactionary activity. 
consequence of appropriate behaviour. But the one who is departing looks forward to the heavenly abode as well. Once and again we encounter descriptions of it. The moribundus is qualified to produce such a sketch: several testaments have the device that he is taken by the angel of death to heaven before he actually dies and moved back to earth in order to inform his own followers and subsequently to give up his life. ${ }^{23}$ True, it is maintained in one place (Pseudo-Philo 33,5) that the deceased will 'forget' everything about the past and will not take an interest in those who are still struggling on this earth. But on the whole, the heavenly world is seen as a realm that exercises its influence on this world, positively or negatively. It is important to see that this view is taken in the fragment of the testament of Amran, that comes from Qumran, 24 a document which in all likelihood is pre-Christian. The 'watchers', who impress themselves on mankind in an adverse way, figure prominently in this text. It is important to note that notions of dualism are constitutive already in part of the Testaments of the XII Patriarchs-Stauffer and Böcher 25 drew attention to this-whereas the portraits of the heavenly world and the forecasting of the future are typical for the later specimens of the Gattung.

Can these two aspects be found in the farewell discourse as well? The readers are admonished to 'remember' (15:20) and to 'keep' what had been said to them. Jesus, the speaker, looks back himself: he speaks of the work he has accomplished (17:4) and his wish that his own may be accomplished as well (17:23), as, indeed, they have proved already to be able to 'keep' his words (17:6). These commandments or exemplary actions (to put it in the terminology of ch. 13) are alluded to once and again (13:34; 14:23). They are constitutive, although they are not spelled out in detail apart from one passage (16:8ff.) a passage which may have a background of its own. ${ }^{26}$

${ }^{23}$ E.g. Testament of Isaac and Testament of Abraham.

${ }^{24} \mathrm{~T}$. Milik, '4Q Visions de 'Amram et une citation d'Origène (Planches III)', Revue Biblique 79 (1972) 77ff.; v. Nordheim, op. cit., I.115f.

${ }^{25}$ See E. Stauffer n.2 above, and O. Böcher, Der johanneische Dualismus im Zusammenhang des nachbiblischen Judentums (Gütersloh 1965).

${ }^{26}$ See B. Lindars \& S.S. Smalley (eds.), Christ and the Spirit (Cambridge 1973) $121 \mathrm{ff}$. 
The second aspect is even more prominent in the farewell discourse. An antagonism is erupting between 'this world' and those who are not of this world. Accordingly, the sentiment that propels this world is characterised as hatred $(15: 18 ; 17: 14)$ and the seriousness of this situation is highlighted by the notion that this world is under the direction of a semipersonal power, 'the prince of this world' $(12: 31 ; 16: 11)$. It is obvious that the faithful encounter nothing but sadness $(\lambda v i \pi \eta$ 16:20), that they cry and weep. Still, this is their fate now, 27 and the term vvv, which is employed with ominous frequency $(12: 31 ; 13: 31 ; 14: 29 ; 17: 13)$, points already to a time dimension in the picture presented in these chapters. Indeed, a change will take place: है $\rho \chi \varepsilon \tau \alpha$ ஸ̆ $\rho \alpha(16: 2,32)$. And the seer, who raises his eyes, is able to pronounce in a proleptic manner that the hour has come already (17:1). ${ }^{28}$ Conversely, it is maintained that the prince of this world is cast out (or: thrown into the netherworld). ${ }^{29}$ What is happening now is seen in relation to this change, indeed it is already an indication of the approaching change. Even the scattering (16:32) or the $\theta \lambda \hat{\imath} \psi \mathbf{i} \varsigma$ $(16: 20 f ., 33)$ are signs of the future, they are, to use the apocalyptic term, woes. Realising this the faithful have no reason to be shaken in their hearts $(14: 1,27)$. Still, they, even they, are in a situation in which they are not able to $\beta \alpha \sigma \tau \alpha \dot{\alpha} \boldsymbol{\varepsilon} \mathbf{}$ everything (16:12). They receive an inkling, so that they are able to believe 'when it has happened'. They certainly need confirmation and even teaching during these dire straits; especially teaching on judgment (16:8), while the world is going to be convicted. The steps in which the drama unfolds, are marked by $\mu$ uкpóv $(12: 35 ; 16: 16)$. At least three stages are clearly indicated. The last stage is alluded to by 'when it happens' or 'accomplishment' ( $\tau \varepsilon \tau \varepsilon \lambda \varepsilon \imath \omega \mu \varepsilon$ 'vor 17:23). A special point emerges at 14:2f. The house with the many mansions is, of course, the temple. ${ }^{30}$ As the earthly temple is often described as

27For the semantic field of $\theta \lambda \hat{i} \Psi \mathrm{i} \varsigma$ see William Horbury \& Brian McNeil (eds.), Suffering and Martyrdom in the New Testament (Cambridge 1981) 99f. ${ }^{28}{ }_{\text {Kai }} \dot{\varepsilon} \lambda \dot{\eta} \lambda \nu \theta \varepsilon v$ (16:32); the positive side of the notion is found in 17:2.

${ }^{29}$ Depending upon whether $\varepsilon \xi \xi \omega$ or $\kappa \alpha \dot{\tau} \tau \omega$ is read.

30 For discussion see F.G. Fischer, Die himmlischen Wohnungen: Untersuchungen zu Joh 14:2f. (Bern/Frankfurt 1975); J. Beutler, Habt keine Angst: Die erste johanneische Abschiedsrede (Stuttgart 1984) 30ff; J. McCaffrey, The House With Many Rooms: The Temple Theme of John 14:2f. (Rome 1988). 
God's tabernacle, it is even more the case with the heavenly realm. Great men are taken to heaven, shown its chambers, in order to return to earth before the final leave-taking. This is about to happen again.

The impression we get from this sketch, is that of a document that impresses teaching on behaviour and, on the other hand, is under the sway of a highly developed apocalyptic system, that at the same time is tied to events in the present and the near future. We rub our eyes and ask ourselves: is this really true? Are we not accustomed to read the chapters in a different way?

The Jewish heritage is obvious, but it is not found in every section with the same density. It is very significant at the end of chapter 13, it also left its marks in 13:31ff. and 14, while it recedes in chapter 15 . It sets the tone again in chapter 16 and it is prominent at the beginning and at the end of chapter 17. This observation may have its importance for the distribution into different farewell discourses-an amalgamation of speeches, which were independent originally, is likely. 31

A further point should not be passed over. 13:36-14.22 contains five questions posed by individual persons. 32 There is nothing similar in chapter 15 . Chapter 16 mentions that the disciples intended to direct a question to Jesus, a question which, however, is answered by the master, before they had had occasion to put it to him. 16:29 contains a choric coda: all the disciples, who are present, confess: now we know. The connection between Jesus and his disciples is of such a calibre that the posing of questions is not any longer appropriate; neither from the side of the disciples nor from the side of Jesus (thus sy). 33

Still, the wealth of parallel material and similarity of language is striking, so much so that it appears justifiable to characterise the farewell discourse as deriving from the

31The decisive observations were made by J. Wellhausen, Das Evangelium Johannis (Berlin 1908) 77ff. Cf. A. Merx, Das Evangelium des Johannes (Berlin 1911) 384f., 423ff. 13:16-14:31 and 15-17 (16) are parallel speeches. It is widely accepted that in 14:30 the text of sy (without $\pi \circ \lambda \lambda \dot{\alpha}$ ) is to be preferred.

32That three of the five questions are redactional (following E. Hirsch, Studien zum vierten Evangelium (Tübingen 1936) 103ff.) is unimportant in this context.

33For the interpretation of the reading of sy see Merx, op. cit., 412 . 
relevant Jewish literature, more precisely as the apocalyptic climax of it. Is this, however, the whole picture?

V.

1. Differences should not, however, be overlooked. The most obvious one is the absence of a description of death and funeral. True, such an account can be found in John 18-19. There is, however, no doubt whatever that these chapters were written by a different hand nor is there any indication that the unit of chapter 13-17 was composed with the intention that it would be concluded by an account of the death of the speaker which then came to be replaced by the passion story we now find in the following chapters. What we actually encounter in the farewell discourse is, we are driven to say, a hint of the ascension rather than of a violent death. 'I am going to the father' (16:28). No allusion is made to Jesus' own violent death, although the hardship the disciples will have to encounter would have given plenty of opportunity to draw attention not only to the persecution of Jesus in the past (15:20), but to the even more frightful experience he will have to encounter in the passion story. This did, however, not happen. The passion of Jesus is neither hinted at nor narrated as it is the case with the source $Q$, which came into circulation without the story of the suffering and death of Jesus. ${ }^{34}$ The scheme of the Jewish Farewell speech is thereby altered. Is it an alteration that is in keeping with and follows on from the Jewish heritage or is it different?

2. Another case in point may be found, if we examine a feature which is typical for the Testament XII Patriarchs. They recommend Levi and Judah; look to them and take them as an example. ${ }^{35}$ The reference is so common that it is almost a cantus firmus in the writing. Passages of this kind are found predominantly at the end of the particular testament (and also at the end of Joseph and Asenath). ${ }^{36}$ That means the general advice is given a specific direction: Levi and Judah are to serve as guarantees for the right way ordained by God. This invites

${ }^{34} C f$. O. Böcher \& K. Haacker (eds.), Verborum Veritas (Wuppertal 1970) $63 \mathrm{ff}$.

${ }^{35}$ E.g. Testaments of Simeon 7:1; Reuben 6:7; Judah 25:1ff; Issachar 5:8; Joseph 19:10; Gad 8:1; Naphtali 8:2; Dan. 5:4-10. $3622 \mathrm{ff}$; concentrated upon Levi. 
comparison with the farewell discourse. Levi and Judah have disappeared, but someone is to lead the disciples and even to acquaint them with new teaching. It is the Comforter, who is identified with the Holy Spirit in part of the five sayings that deal with him. It is not one of the company to whom the disciples are advised to hold fast but someone who is, so to speak, a new phenomenon. He is not part of Israel's history (as Levi and Judah are), but a new element hitherto unknown. He stands in the line of Jesus, while Judah and Levi do not render unnecessary the sons of Reuben, etc., do not replace the direction indicated by the respective figures. Is this a development of the Jewish scheme or a substantial departure?

3. The farewell discourse contains one parable which is reflected upon at some length; the vine, and another, which is only briefly referred to; the woman giving birth to an öv $\theta \rho \omega \pi 0$ s (16:21f.). The parabolic form is, as far as I can see, absent from the Jewish farewell material. 15:5 drives home the point: in connection with Jesus you will bear much fruit. The related parable in chapter 10-maybe it has to be placed in the context of the farewell discourse speeches-emphasises that the sheep 'know' and listen to the voice of the shepherd. The two parables do not only emphasise the connection between the speaker and those who are his own but describe it in so many words as indispensable, as the sine qua non of existence. The form, unusual as it is in this context, corresponds to the singularity of the concentration on the speaker. The parable on the birth does not fasten on the birth pangs-the term woives is not even mentioned (as 15:2 mentions the cleansing only in passing) but on the coming into existence of a new ơv $\theta$ pwros.

4. The Jewish farewell discourses narrate, rehearse and emphasise God's dealings with Israel in the past; 37 the life of the speaker serves as an example. Such 'testimonies' (if we may call them so) are not drawn attention to in these chapters. There are, however, dealings of God, which are considered relevant and which are alluded to once and again. Those who had been given to Jesus, kept his word-therefore the father is implored to protect them in future $(17: 11,15)$, so that they may become perfected (17:23). The story of God's selection of Jesus' disciples, their walking with their master, the protection given

37Pseudo-Philo 23:4-8; 29:4; Jubilees 20:5; cf. Stauffer, passim. 
to them by Jesus, the success Jesus had with them, while the world extended the hatred for Jesus against them as well seems to have replaced this part of the Jewish pattern. Jesus' prayer for their future, his manifest declaration for them and the commissioning of them are the result.

This is surprising, as chapter 17 starts with a different theme, with the glorification of Jesus himself (vv. 2, 4f.). Inconsistencies of style and vocabulary make it obvious that two sources have been worked together at the beginning of the chapter. Might it be that the rehearsal of the history of the disciples and the covenantal pledge for the future was felt so important that it not only replaced the traditional theme but caused the abbreviation of the theme initiated in verse 2 ?

Similar ideas are found in 15:3, 8-12; likewise in 10:7f., 14 (without $\kappa \alpha \lambda$ ós), 10:16 a/b. Bultmann had placed chapter 10 after 12:34-6.38 It is in fact an Abschiedsrede, which came to be linked with pieces of a different character. It is here that reference to the past of the Israelites is made explicitly: other men, many have come before. ${ }^{39}$ The reference is, however, made with the intention of excluding them; the sheep did not heed them, because they were all thieves and robbers, without exception (10:8).

The observations, positive and negative, hold together and show that the reference to and concern for the disciples replaced the contemplation of the past of Israel in the farewell discourse. This is so, because they, to whom Jesus addresses himself, are the very है $\rho \alpha$ of $\operatorname{God}(14: 10 ; 17: 4)$, comparable to the work of creation.

5. The call to love each other, presented with nuances, may be explained in a similar way. The Jewish testaments give detailed instructions on behaviour and supplement the Old Testament in this way. .0 No supplementation of this kind is produced here. Instead, an exclusive concentration is carried out: it is the New law, Jesus' law that matters.

6. This leads back to a passage which has been touched on already: 14:2f. The verses claim what had been maintained for

38R. Bultmann, Das Evangelium des Johannes (Göttingen 1950) 272.

${ }^{39}$ See E. Bammel \& C.F.D. Moule, Jesus and the Politics of his Day (Cambridge 1984) 123.

${ }^{40} \mathrm{As}$ they are put in the mouths of the patriarchs, they predate Moses and can be regarded as being presupposed in his legislation. 
the great men of the past for Jesus as well-either hypothetically or actually-(the text is not in its original state), both possibilities are open depending on its restoration. 41 The motif of an ascent during Jesus' lifetime (or rather at the end of it) is, however, in no way worked out. It only serves as a

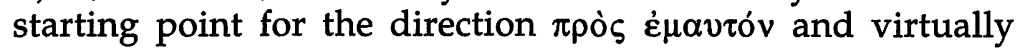
leaves behind the notion of journeys and abodes. What $\dot{\alpha} \rho \kappa \varepsilon \hat{\imath}$ $\dot{\eta} \mu \mathrm{i} v(\mathrm{v} .8$ ) is the only concern.

7. Equally significant is the lack of predictions which are so prominent in Jewish literature. 14:29 and 16:4 contain only the

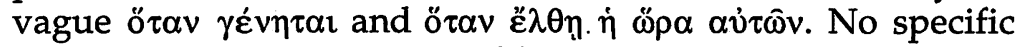
sketches are drawn or timetables worked out. Future events will only serve to enable the disciples to believe or to remember. This is expressed most clearly in 13:19.

8. Nor is there any evidence for literary dependence of the Johannine farewell speeches from Jewish material of a similar kind. There are no citations ${ }^{42}$ nor allusions nor can a similar constellation of themes be traced.

9. The Jewish writings in question carry the title: testament. Here and there they contain the advice to put one's affairs in order, to write a will or to make use of the services of someone who is able to do so. A juridical meaning is present, 43 although it is apparent in the overarching covenant idea rather than in individual orders. This element is not absent in the farewell discourse either. It does indeed come to the surface in a surprising way. It is stated in 14:18 that Jesus will not leave his disciples as orphans-a phrase which is normally given a solely metaphorical meaning but which may be in need of a closer interpretation. Chapter 17 speaks of what Jesus is about to give to his disciples. This comes to its climax in v. 24ff., sentences which abound in juridical terminology. God is implored as the righteous father. ${ }^{44}$ Jesus stipulates his will. He has revealed, that means he has entrusted his own with God's name and is about to entrust them with it again. This $\gamma v \omega p i \zeta \omega$ replaces the $\delta 1 \alpha \tau i \theta \varepsilon \mu \alpha$, which is employed in Luke 22:29 in the report of the

41The main discussion can be found in Wellhausen, 62ff.; Hirsch, 29; Merx, $36 \mathrm{ff} ;$ Bultmann, $462 \mathrm{ff}$.

${ }^{42} \mathrm{As}$ is sometimes the case in apocalyptic literature.

${ }^{43}$ Differently v. Nordheim II.144.

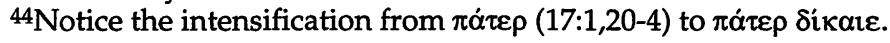


same scene. 45 The disciples are heirs of God's name or his innermost secret, which is love. This love will not be taken away from them after Jesus' departure. The juridical terminology is employed at this point in order to bring out the seriousness of the meaning as strongly as possible. What is said here does not allow a loose interpretation. It is a covenant like the one on Mount Sinai and, indeed, it replaces the former one. The structure of the Jewish testaments is noticeable at this point, very much so; but in substance it is a departure, a complete break with the past, that we encounter here.

The nine features dealt with point in the same direction. they do not only show a departure from the structure of the Jewish testaments but indicate a different message, a message which, although couched in Jewish terminology, is different in its contents and not just a further development. 12:30 can be taken as a motto for the whole context. The apocalyptic scenario unfolds itself $\delta \mathrm{t}^{\prime} \dot{v} \mu \hat{\alpha} \varsigma$, it is only of preliminary importance.

\section{VI.}

We encounter another Gattung in early Christian literature, the speeches of the resurrected one, which become the vehicles for the expression of Christian truths. While the risen Lord is only alluded to in Mark, while he gives only short orders in the three other gospels (and also in the gospel to the Hebrews), he is portrayed as having conversed endlessly with his disciples in a number of apocryphal works. It is stated in the Apocalypse of Peter that Jesus was sitting on the Mount of Olives when he uttered his sayings and that he was taken to heaven from there. The Testamentum Domini is said to have been promulgated in Galilee, while the Gespräche, published by C. Schmidt, 46 are supposed to have taken place after the resurrection and concluded by Jesus' withdrawal to heaven. The scene in which the discourse is set is not mentioned in Pistis Sophia and Ap. Thomae, although it is clear that it is not the earthly Jesus who addresses his disciples. This Gattung seems to have replaced the testaments in Christian literature. The special position of the Johannine farewell discourse is illustrated by this. It still is

${ }^{45}$ Bammel, op. cit., $74 \mathrm{ff}$.

${ }^{46} \mathrm{C}$. Schmidt, 'Gespräche Jesu mit seinen Jüngern nach der Auferstehung', TU 43 (Leipzig 1919). 
dependent on the Jewish infra-structure, whereas the speeches of the Resurrected one have departed from this. Their form is a novum, whereas in substance many of them are filled with Jewish apocalyptic material. Thus the farewell discourse of the fourth gospel is from a literary point of view the product of a transitional phase.

What has been achieved in these chapters is all the more striking. The Jewish material is partly used like stones from a quarry and partly it is reduced to a formal infrastructure, in comparison with which or rather in contrast with which a new relationship, differing from the physical bonds of blood and inheritance is visualised. There were, as far as we can see, no preliminary literary formations. The farewell discourse or rather the three farewell discourses appear on the scene like a Phoenix rising from the ashes of the Jewish farewell speeches. They are virtually identical in their scope and indicate an intellectual vigour without any parallels.

As speedily as they made their appearance they disappear again. Valde mirabile est. 